\title{
Impacts of El Nino on Rainfall and Its AgrocltmaticIncidences in the Zanzan Region: North-East of Cote d'Ivoire
}

\author{
Kouakou Bernard DJE ${ }^{1}$, Abé Delfin OCHOU², Zilé Alex KOUADIO*, Kolotioloma Alama \\ COULIBALY ${ }^{1}$ \\ ${ }^{1}$ Société d'Exploitation et de Développement Aéronautique, Aéroportuaire et Météorologique (SODEXAM) 15 B.P. \\ 990 Abidjan 15, (Côte d'Ivoire). \\ ${ }^{2}$ Laboratoire de Physique Atmosphérique et de Mécanique des Fluides (LAPA-MF), Université Félix Houphouët \\ BOIGNY, 22 B.P. 582 Abidjan 22 (Côte d'Ivoire). \\ ${ }^{3}$ Université Jean Lorougnon GUEDE (UJILoG) de Daloa, BP 150 Daloa, Côte d'Ivoire \\ Email: kazile2004@yahoo.fr
}

\begin{abstract}
The aim of this study is to analyze the manifestation of rainfall variability in the district of Zanzan level during El Niño episodes and to evaluate its agro-climatic impacts. SODEXAM climate data and Sea Surface Temperature (SST) of El Niño 3.4 area were used. The composite analysis made it possible to evaluate the impacts of the El Niño phenomenon on rainfall. INSTAT ${ }^{+}$ v3.30 software was used for the analysis of agro-climatic events. The results indicated average rainfall deficits from 10 to $44 \%$ in the district from October to April. Rainfall patterns are disrupted in the El Niño year. Crops seasons are late and end early in Bondoukou, Bouna and Tanda. This disturbance affects agro-climatic events by shortening the growing season in the Zanzan on average 21 days in El Niño year.
\end{abstract}

Keywords: Climatic variability, El Niño, agro-climatic event, Zanzan region, Côte d'Ivoire

\section{Introduction}

Climate change is a serious concern for the socio-economic development of vulnerable populations in the developing countries (Mbalamona, 2015). Nowadays, the climate changes are one of the greatest challenges mankind must face with in this 21st century [1]. Some interannual scale studies conducted highlight a significant statistic correlation between El Niño and rainfall [2-6]. In West Africa, the El Niño issue is always associated with a lack of rainfall, namely in the Sahel region. Studies from [7-9], based upon observations and digital simulations show that the multi-century evolution of surface temperatures of sea after 1970 reinforces the impact of El Niño events on the West Africa's monsoon reducing the advent of water heat and accentuating rainfall deficit. Agriculture and forestry are probably the two sectors most vulnerable and most sensitive to climatic fluctuations. In the African tropical zones, agriculture undergoes the impacts of the variability and climate change with the reduction of the vegetation period duration. The dreadful consequences are the tremendous degradation of lands and the environment, the reduction of subsistence means, the high risk for famine, to poverty and a meaningful gap between social inequalities.

In the Zanzan region, the climate variability through the spread of rain importantly influences the socio-economic activities. The studies of [10] have shown that in addition to the drop in the annual volume of rainfalls in Doropo from 1977 to 1981, the lengh of the season with no rain or the rainfall that less than $5 \mathrm{~mm}$ has risen by 7 to 14 periods of ten days. The agricultural yields are closely linked with the mastery of rainfall and an agricultural calendar.

The aim of this paper is to help to understand the events of climate variability and its agro-climatic impacts in the Zanzan region. It is in the framework for applied research assistance for climatology for the agricultural sector.

\section{Presentation of the Research Area}




\subsection{Geographical Location}

The Zanzan region is located in the North-east of Côte d'Ivoire between the longitudes $4^{\circ} 30$ and $2^{\circ} 30$ west, and the latitudes $7^{\circ}$ et $10^{\circ}$ North. The region covers up about an area of $38000 \mathrm{sq} . \mathrm{km}$. It is limited in the North by the Republic of Burkina Faso, in the East by the Republic of Ghana,in the South by the regions of M'bahiakro, Daoukro and Agnibilékro, in the West by Ferkessedougou and Dabakala regions. Figure 1 below presents the geographical location of the Zanzan region.

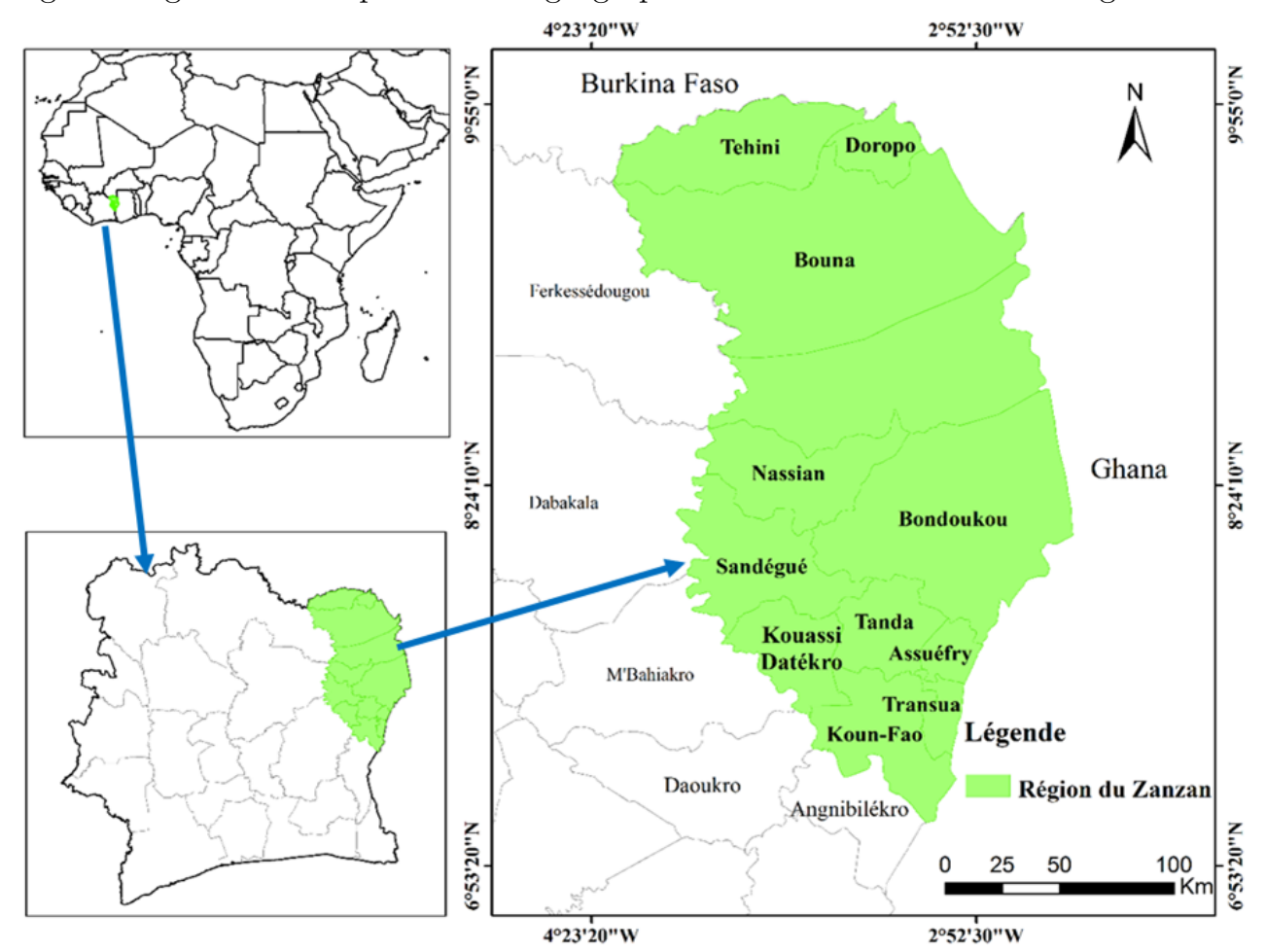

Figure 1. Geographical location of the Zanzan region

\subsection{Climate}

The Zanzan region has two (2) rainfall regimes from the South to 9th parallel. The climatic condition is bimodal and is described as follows:

- From March to June: great rainy season. The most rainy months are May and June with an average of $159.2 \mathrm{~mm}$ in Bondoukou in May.

- Fom July to August: Rainy inter-season marked by the weaknesses in rainfalls;

- From September to October: Small rainy season;

- Fom November to February: great dry season characterized by a drastic drop in rain. December and January are the driest months. The averages amont of rainfall are not more than $10 \mathrm{~mm}$.

\subsection{Socio-economic Activities}

Agriculture is the main source of income for the population. It occupies more than $90 \%$ of that population and is dominated by traditional family exploitation. Crops play an important part in the activities [11]. They are: yam, maize, rice, groundnut, millet, sorghum and cassava. The main crop for commercial purpose is cashew nut.

\section{Material and methods}

\subsection{Material}




\subsubsection{Climate data}

The climate data used in this study are from the SODEXAM data base. SODEXAM is a center for the exploitation and airport development, aeronautics and weather forecasting. They deal with volume of rain of the synoptic station of Bondoukou and the various rainfall centers of the Zanzan region (Table 1). The data were collected on a daily basis scale and analyzed on a daily, ten days period, monthly and annual scale. They have been reviewed and corrected referring to previous studies conducted by [12].

Table 1: Network for meteorological measurement and data period

\begin{tabular}{lllll}
\hline Stations & Longitude & Latitude & Period & Station Type \\
\hline Bondoukou & -2.783 & 8.050 & $1961-2010$ & Synoptic \\
Bouna & -2.983 & 9.267 & $1961-2010$ & Rainfall \\
Doropo & -3.317 & 9.817 & $1971-2010$ & Rainfall \\
Koun-Fao & -3.250 & 7.483 & $1971-2010$ & Rainfall \\
Nassian & -4.467 & 9.400 & $1971-2010$ & Rainfall \\
Tanda & -3.167 & 7.783 & $1961-2010$ & Rainfall \\
\hline
\end{tabular}

\subsubsection{Sea surface temperature data}

The sea surface temperature data of Niño 3.4 region, (latitudes $5^{\circ} \mathrm{N}-5^{\circ} \mathrm{S}$ and the longitudes $120^{\circ}$ $\left.170^{\circ} \mathrm{W}\right)$ have been used by season. Those data are from the NOAA/CPC center for the period 1951-2010. The occurrences of El Nino on the period for the study are noticed in 2009-2010, 2006-2007, 2004-2005, 2002-2003, 1997-1998, 1994-1995, 1991-1992, 1986-1988, 1982-1983, 1977-1978, 1972-1973, 1968-1969, 1965-1966, 1963-1964 [13].

\subsubsection{Software}

The software INSTAT+ v3.30 [14] was used for the calculation of the duration of the various seasons and for the analysis of dry seasons. It was designed by the Center for statistics of the University of Reading and by the British Weather Forecasting Service (UK Met Office) from the United Kingdom.

\subsection{Methods}

\subsubsection{Evaluation of "EL NINO" impacts on rainfall}

The composite analysis method is utilized to highlight the existence of teleconnexions between some variables. It was helpful for the analysis for relationships between irregularities from oceanic surface temperature and their impacts on rainfall variability. The hottest and coldest phases of the oceanic zones are determined from the indication of ocean surface temperature. These indications were used to identify the periods (years and seasons). Consequently, the values lower than $-0.5^{\circ} \mathrm{C}\left(<-0.5^{\circ} \mathrm{C}\right)$ correspond to a cold phase whereas those higher than $0.50 \mathrm{C}$ are hot situations $[15 ; 16]$. However, the seasonal rainfall average $(\bar{M})$ for the various oceanic phases were determined and compared with the average $\left(\bar{M}_{n}\right)$ of the normal rainfall (1971-2000). The seasonal composites (C) were elaborated in determining the percentage of rainfall pluralities in relation with the average of the following formula:

$$
C=\frac{\bar{M}}{\bar{M}_{n}} \times 100
$$

The characterization of the composite was done by adopting the limit for percentages to the average in Côte d'Ivoire [15]. Therefore, the values of C less than $80 \%(<80 \%)$ correspond to a deficit situation. The percentages between 80 and $120 \%$ show a close situation to normal whereas those higher than $120 \%$ $(>120 \%)$ inform us about a excess situation.

\subsubsection{Analysis of Rainfall Profile}

For the calculation of rain occurrence probability, the method of Markov was utilized. That method is based upon the study of law of $\mathrm{Xn}+1$ as $\mathrm{Xn}=\mathrm{in}$. It is an application of the formula of Bayes that describes the conditional probability of an event $\mathrm{A}$ if the probability $\mathrm{B}$ is known. The formula is the ensuing:

$$
P(A / B)=\frac{P(A \cap B)}{P(B)}
$$


A chain of Markov's is defined as follows:

Be it $\left(X_{n}\right) n \in N$ a follow-up of random variables of $(\Omega, \mathbf{A}, \mathrm{P})$ within a space $\mathrm{E}$ finished or countable named space of states. It is said $\left(X_{n}\right) n \in N$ is a Markov's chain if and only if:

$$
P\left(X_{n}+1=j \mid X_{n}=i, X_{n}-1=i_{n}-1, \ldots X_{1}=1, X_{0}=0\right)=\left(P\left(X_{n}+1=j \mid X_{n}=i\right)\right.
$$

for any $n \in N$, for any state $\mathrm{j}$ and for any follow-up of states, $\mathrm{i}_{0}, \mathrm{i}_{1}, \ldots \mathrm{i}_{\mathrm{n}-1}$, $\mathrm{i}$, for which the conditional probability has a meaning, that is:

$$
P\left(X_{n}=i, X_{n}-1=i-1, \ldots, X_{1}=1, X_{0}=0\right) \succ 0
$$

If the probability does not depend on $\mathrm{n}$, that is, if:

$$
P\left(X_{n}+1=j / X_{n}=i\right)
$$

It is said that Markov's chain is homogenous.

$$
\forall n \in N, \quad P\left(X_{n}+1=j \mid X_{n}=i\right)=P\left(X_{1}=i \mid X_{0}=i\right)
$$

The characteristic of a Markov's chain in agro-climatology is that in such a process, the prediction for the future from the present time does not require the knowledge of the past as any useful information for the prediction of the future is contained in the current state of the process. Based upon that characteristic, rain probability was calculated by means of the INSTAT + software. The entry data were the daily rainfall data from the stations for measurement. It was about the determination of rain occurrence probabilities (possibility of rain) for a given order $(0,1,2$, etc...) and for two situations: dry or rainy.

Order 0: the day is whether rainy or dry marked ' $r$ ' or'd'

Order 1: Rain probability occurrence based upon the situation of the previous day

- a rainy day is preceded by a rainy day : 'rr'

- a rainy day is preceded by a dry day 'rd'

- a dry day is preceded by a rainy day ' $\mathrm{dr}$ '

- a dry day is preceded by a dry day 'dd'

Order 2: Rain occurrence probability based on the situation of the two previous days

- a rainy day is preceded by a rainy day and by a dry : 'rrr'.

- a rainy day is preceded by a rainy day and by a dry day : 'rrd'.

- a rainy day is preceded by a dry day and by a rainy day: 'rdr'.

- a rainy day is preceded by two dry days 'rdd'.

- a dry day is precede by two dry days 'ddd'

- a dry day is preceded by a dry day and by a rainy day: 'ddr' .

- a dry day is preceded by a rainy day and by a dry day: 'drd'.

- a dry day is preceded by two rainy days: 'rdd'.

In this study, only the occurrence probabilities of order 0 were considered to identify rain possibility everyday of the year. This brings about relying on the period of observations of rains, the number of times where a given day is rainy and the number of times when it is dry. The years 1973, 1983, 1998, 2002 and 2007 known as dry were particularly analyzed in order to scrutinize the local variability of rain occurrence in relation to the climatic phenomenon "EL Niño" from a global picture.

The data are represented under the form of a curve highlighting the probability on a daily basis. The curve with a sinusoidal orientation shows rain probability. The software INSTAT+ permitted the researchers to adjust the curves utilizing a harmonic function.

\subsubsection{Agro-climatic events analysis}

A rainy season is characterized by a couple of agro-climatic events. These events are the date of crop season and the duration of the crops seasons. The researchers can also mention the largest dry sequences during the sensitive phase of plants. With daily rain data, an analysis of agro-climatic events is done in relation to the years named normal and the years in which the El Niño phenomenon is observed to evaluate the impacts of that phenomenon on agricultural activities.

\subsubsection{Start, end and duration of crops seasons}

For the determination of crop seasons, the method of [15] based on some specific criteria and the Julian calendar was used. It was adapted to the local climate in defining the ensuing criteria for Côte d'Ivoire [16]. 


\section{- Beginning of agricultural season}

The beginning date of the agricultural season $(\mathrm{X})$ ranges from the date $(\mathrm{Y})$ when the rainfalls collected within two consecutive days represent at least $20 \mathrm{~mm}$ and when there is no dry period of more than seven (7) consecutive days is not effective during the next 30 days. The date $(Y)$ that will be kept is the earliest date that satisfies the beginning criteria of the vegetative season.

\section{- End of agricultural season}

The end of the season takes place after the date $(Z)$ when the stock in groundwater is inferior or equal to a volume of given water. For this study, that volume of water is fixed to $5 \mathrm{~mm}$ corresponding to the potential daily evaporation of the research area. The date $(\mathrm{Z})$ will be considered as the theoretical date from which the season is supposed to end.

A statistical analysis based upon the quantiles permits to classify a date within the following categories:

- The early dates are comprised between the quantiles (les quintiles) $20 \%$ and $40 \%$;

- The normal dates are comprised between the quantiles (les quintiles) $40 \%$ and $60 \%$;

- The late dates are comprised between the quantiles (les quintiles) $60 \%$ and $80 \%$.

The periods before $20 \%$ and after $80 \%$ are considered as very premature periods respectively.

The median date (quintile 50\%) is the date that is kept as normal date of beginning or end of the vegetative season for the succession of years considered. The duration of the humid season is obtained by the difference between the dates of beginning and vegetative end within the same year.

\subsubsection{Calculation of dry spells}

The information about dry spells for a crop season is important. Those sequences are periods with no rain in the beginning of the rainy season. A "dry" day is defined as a day with no rain. The calculation of the dry spells starts from the last rain which is higher than $0.1 \mathrm{~mm}$. The method of Sivakumar was used and it required successions of daily rainfall data. The function Gamma is incorporated in the software Instat [17]. We calculated the probabilities of dry periods of more than 5, 7 and 10 days from the date of beginning of rains. We took into account the maximum duration of dry period within the following 30 days from the beginning date of rainy seasons and particularly within the years 1973, 1983, 1998, 2002 and 2007.

\section{Results and discussion}

\subsection{Results}

\subsubsection{Intra-seasonal variability analysis of rainfall}

Table 2 presents the seasonal rainfall anomalies in (\%) within the year El Niño in comparison with the normal 1971-2000 in the Zanzan region. That situation caused an early settlement of the dry season as soon as the climatic season from September to November (SON) starts and was centered on October with a serious deficit in rainfall of $12 \%$. That deficit kept going on all the dry season long turning that dry season into severe drought period, namely from November to January (NDJ). The deficit still continued until April with lack of rain that could reach $44 \%$ between January and March. The rainfall that varied between -10 and 10\% with the exception of the climatic season from June to August (JJA) indicated rainfall excess that reaches $13 \%$ of the normal level.

On the department's scale, even if the researchers notice some disparities in the impacts on rainfall assessment, it is noted that except Koun Fao, the other departments reveal some deficits in rainfall from September to April, that is, eight (8) months where the need for water is not satisfied. In Koun Fao, the deficit in rainfall is from November to May. The average deficit in rainfall is calculated for every department from September to April respectively, highlight 14\% for Bondoukou, Bouna (23\%), Tanda $(25 \%)$, Nassian (16\%), Kounfao (12\%) and34\% for Doropo (34\%). That was to show that the impacts of the phenomenon El Niño have a spatial extension as well.

In Bondoukou, only the period from April to June (AMJ) presents a significant situation. Within the year, the positive variance in rainfall are weak enough (less than 10\%) on the humid season with a dry beginning marked by an average of rainfall deficit of $23 \%$ on the climatic season from February to April (FMA). That is the sign for the delay in the settlement of the humid season. During the period known as dry (November to February), the deficit in rainfall reaches $24 \%$. 
In Bouna, the periods covering up the climatic seasons from May to July and from June to August (JJA) highlight significant rainfall surplus (variance higher than 10\%). During the other climatic seasons, rainfall is close to the normal level from August to September and short early in the beginning of October. The only dry season settles very early. The average deficit in rainfall registered from October to April is $26 \%$ indicating the tremendous impact of the phenomenon El Niño on hydrous season.

Table 2. Assessment of seasonal rain (\%) in the Zanzan region in years El Niño referring to the normal 1971-2000

\begin{tabular}{lllllllllllll}
\hline Stations & DJF & JFM & FMA & MAM & AMJ & MJJ & JJA & JAS & ASO & SON & OND & NDJ \\
\hline Bondoukou & -9.7 & -33.8 & $\mathbf{- 2 2 . 7}$ & -9.3 & 35.5 & 2.1 & 1.2 & 4.3 & -0.5 & -2.6 & 2.0 & $\mathbf{- 3 1 . 6}$ \\
Bouna & -7.6 & $\mathbf{- 5 6 . 0}$ & $\mathbf{- 3 6 . 1}$ & $\mathbf{- 2 9 . 5}$ & 3.5 & 22.1 & 17.2 & 1.2 & -5.7 & $\mathbf{- 1 1 . 9}$ & -0.3 & $\mathbf{- 3 8 . 4}$ \\
Tanda & $\mathbf{- 1 7 . 2}$ & $\mathbf{- 5 1 . 7}$ & $\mathbf{- 3 2 . 2}$ & -8.3 & 15.0 & 11.2 & 16.8 & 4.8 & $\mathbf{- 1 1 . 8}$ & $\mathbf{- 2 1 . 5}$ & $\mathbf{- 1 5 . 7}$ & $\mathbf{- 4 4 . 5}$ \\
Nassian & $\mathbf{- 2 0 . 9}$ & $\mathbf{- 3 0 . 7}$ & -6.2 & -1.9 & 6.6 & 4.1 & 22.7 & 12.6 & -5.1 & $\mathbf{- 1 3 . 9}$ & $\mathbf{- 1 2 . 8}$ & $\mathbf{- 3 6 . 8}$ \\
KounFao & $\mathbf{- 3 4 . 3}$ & $\mathbf{- 1 9 . 0}$ & $\mathbf{- 6 . 3}$ & $\mathbf{- 9 . 2}$ & $\mathbf{- 1 8 . 1}$ & -8.7 & 8.9 & 8.0 & 6.9 & 5.2 & -3.9 & $\mathbf{- 3 2 . 9}$ \\
Doropo & $\mathbf{- 5 3 . 9}$ & $\mathbf{- 6 9 . 9}$ & $\mathbf{- 2 0 . 2}$ & $\mathbf{- 3 . 3}$ & -4.5 & -5.5 & 14.4 & -1.2 & -6.8 & $\mathbf{- 2 6 . 2}$ & $\mathbf{- 3 7 . 8}$ & $\mathbf{- 5 3 . 8}$ \\
Moyenne & $\mathbf{- 2 3 . 9}$ & $\mathbf{- 4 3 . 5}$ & $\mathbf{- 2 0 . 6}$ & $\mathbf{- 1 0 . 2}$ & 6.3 & 4.2 & 13.5 & 4.9 & -3.8 & $\mathbf{- 1 1 . 8}$ & $\mathbf{- 1 1 . 4}$ & $\mathbf{- 3 9 . 7}$ \\
Région & & & & & & & & & & & & \\
\hline
\end{tabular}

4.1.2 Comparative analysis of rainfall profiles in El Niño years and in normal years.

The remarks on the seasons are illustrated by rain probabilities within each area. Figures 2, 3 and 4 present the evolution of rain probabilities as threshold of rain in the year with normal situation and with El Niño situation. By fixing the probability of $20 \%$ as reference point for the analysis, it makes the information clear.

In Bondoukou, the curves highlight the bimodal character of the rainfall. The peaks of the two rainy seasons are well identified with the indicated periods, that is, May and June for the first season, September and October for the second season. However, we remark a packing down of rain probabilities between $20 \%$ in year El Niño till the end of the first ten days period of May whereas that limitation of $20 \%$ is covered with the second period of ten days of March in normal year. That situation confirms the delay in the advent of the first rainy season. Moreover, in year El Niño, the inter-season (small dry season) really becomes dry with rain probability less than $20 \%$ of the third period of ten days from June to the end of the second period of ten days of August. In normal year, the probability of rain is not below 20\%. For the end of rainy seasons, the threshold of $20 \%$ is crossed in the second period of ten days of October whereas in normal year, that threshold is crossed with the first period of ten days of November which confirms the premature end of the rainy period.

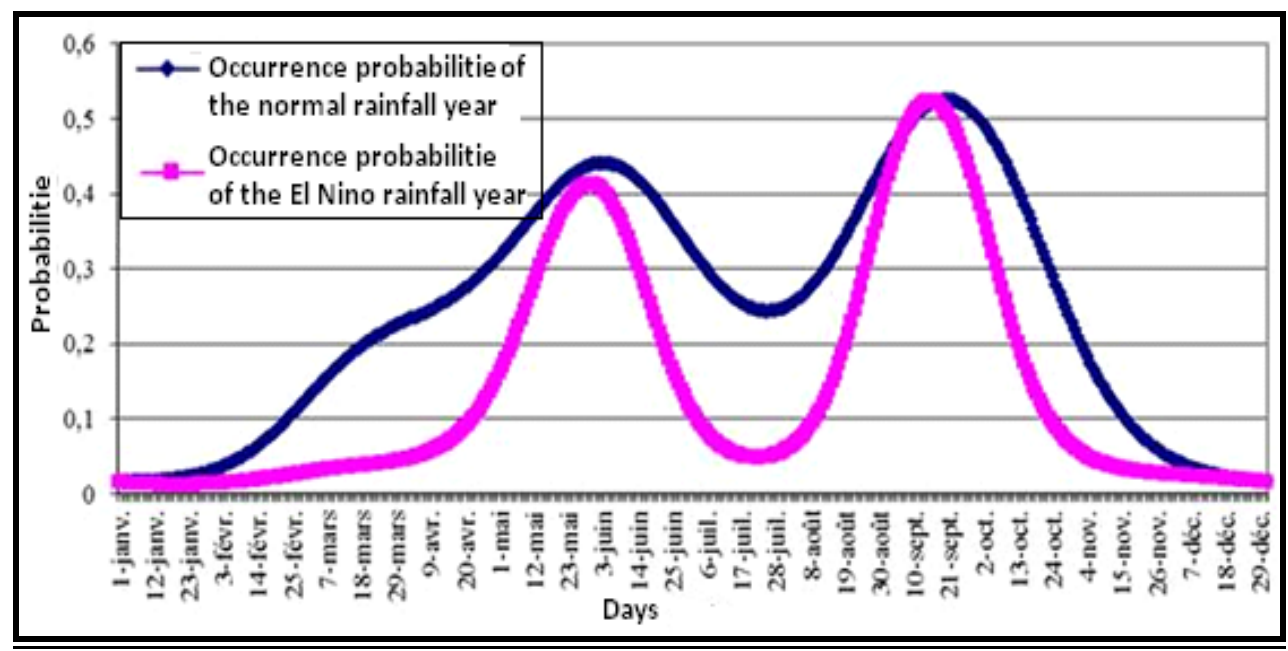

Figure 2. Rain probability occurrence at Bondoukou station 
In Bouna, the curves show a quasi-bimodal characteristic of normal rainfall with a mitigated peak from May to June and a disappearance of the peak from May to June in year El Niño. We notice a packing down of rain probabilities below $20 \%$ in year El Niño until the end of the second period of ten days of August whereas that threshold of $20 \%$ is crossed with the third period of ten days of April in normal year. For the end of the rainy seasons, the threshold of $20 \%$ is crossed in the first decade of October whereas in normal year, that threshold is crossed in the second period of ten days of October. This current analysis reveals that in year El Niño, the number of days where rain probability is higher than $20 \%$ is significantly weak, about 46 days for 179 days in normal year.

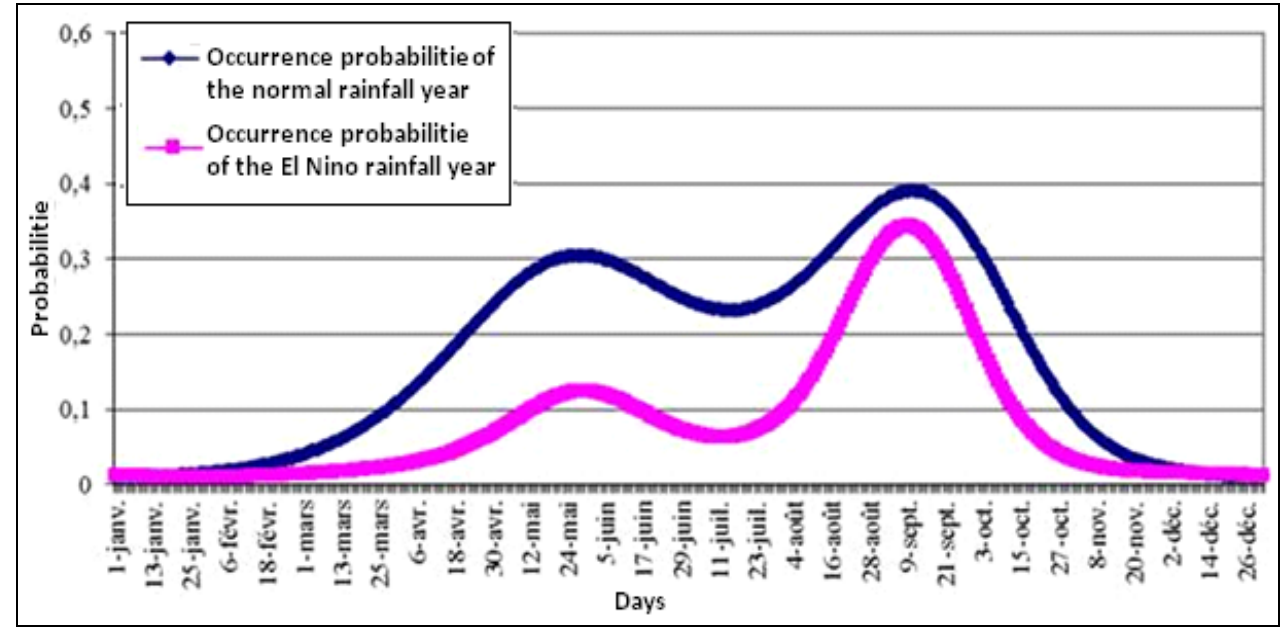

Figure 3. Rain probability occurrence at Bouna station

In Tanda, the orientation of the curves indicates a bimodal characteristic of the normal rainfall in Tanda region and a disappearance of the second rainy season in year El Niño. There is a packing down of probabilities of rain below $20 \%$ in year El Niño till the end of the second period of ten days of May whereas that threshold of $20 \%$ is crossed with the third period of ten days of April in normal year. The second rainy season is stable in normal year with probabilities occurrence of rain for more than $20 \%$ between mid-august and the third period of ten days of October. In year El Niño, rain probabilities which are lower than $20 \%$ appear with the second period of ten days of June and remain persistent till the end of the year making the second season of rain disappear completely.

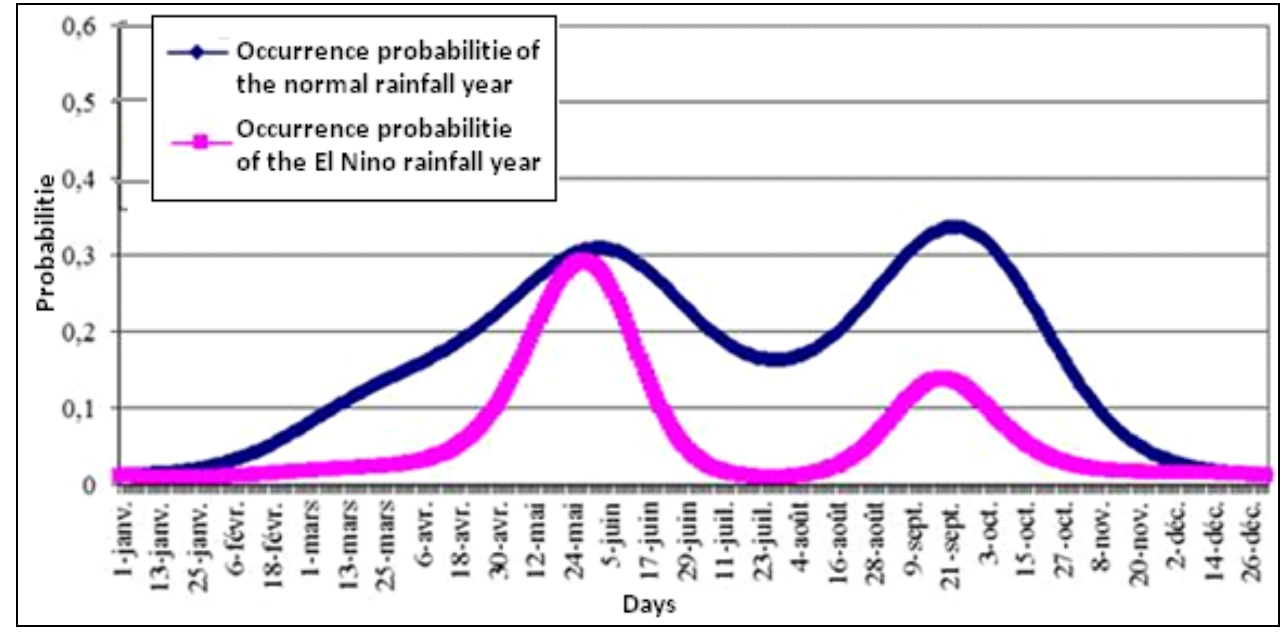

Figure 4. Probability occurrence of rain at Tanda station

\subsubsection{Impacts of El Niño on agro-climatic events}

\subsubsection{Beginning, ends and duration of crops seasons}

The table 3 presents the beginning dates of rainy seasons within the normal years and year's 
occurrence of the phenomenon El Niño in the Zanzan region and their differences. The analysis reveals that the normal beginning of the rainy season in the Zanzan region is noticeable in the first period of ten days of April in Bondoukou, in the second period of ten days of April in Tanda and Koun Fao regions in the first period of ten days of May in Nassian, in the second period of ten days of May in Bouna and in the third period of ten days of May in Doropo. The normal end of the rainy season is noticed at the end of the second period of ten days of July in Tanda and Koun Fao in the third period of ten days in Nassian and at the end of the third period of ten days of July in Bondoukou. In Bouna and Doropo, the end of rains is seen in the third period of ten days of October. In the year where the phenomenon El Niño is observed, the first rainy seasons begin in the first period of ten days of May in Bondoukou, Nassian and Doropo in the third period of ten days of April in Koun Fao and in the first period of ten days of June in Bouna. In Tanda and in Doropo, the season begins in the first period of ten days of April and in the first period of ten days of May, respectively. The end of the rainy season in years El Niño is noticed on the average level in the first period of ten days of July in Nassian, in the second period of ten days of July in Tanda, Bondoukou and in the third period of ten days of July in Koun Fao. In Bouna and Doropo, it is noticeable in the first period of ten days of October.

The comparison of the beginning and ends of rainy seasons in normal years and in year El Niño shows a delay of the rainy seasons, namely in Bouna with 22 days, in Bondoukou with 32 days and in Koun Fao with 10 days. However, in case of the phenomenon El Niño, it rains early in Tanda and in Doropo with 14 days and 18 days ahead respectively. A sudden end of the rainy seasons is almost observed in the whole region.

Table 3. Average dates of beginning, end and duration of rainy season in the Zanzan District

\begin{tabular}{lllllll}
\hline Areas & \multicolumn{2}{l}{ Average dates of beginning } & \multicolumn{3}{c}{ Average dates of end } \\
& Normal & Years & Differences & Normal & Years & Differences \\
& Years & El Niño & & Years & El Niño & \\
\hline Doropo & 24-May & 6 May & Early 18 days & 23-Oct. & 1 Oct & Early 22 days \\
Bouna & 13- May & 4 June & Delay of 22 days & 23-Oct. & 9 Oct & Early 14 days \\
Nassian & 08- May & 8 May & normal & 22-July. & 8 July & Early 12 days \\
Koun Fao & 14-April. & 24 April & Delay of 10 days & 20- July. & 21 July & normal \\
Bondoukou & 6-April. & 8 May & Delay of 32 days & 31- July. & 17 July & Early 14 days \\
Tanda & 19-April. & 5 April & Early 14 days & 19- July. & 12 July & Early 7 Days \\
\hline
\end{tabular}

The duration of the rainy season in the stations of Doropo, Bouna, Nassian, Koun Fao, Bondoukou and Tanda are indicated in table IV. The differences in the duration of crops season in normal years and in years El Niño are mentioned as well. The table presents the duration of crops season for six (6) areas from the Zanzan region. The average duration of crops season is 121 days in normal year for 100 days in years El Niño which is a reduction of the crop seasons for an average of 21 days for the Zanzan region. This average shows some disparities for the areas. The impact of the phenomenon seems less remarkable in Doropo whereas in the other areas, the occurrence of the phenomenon El Niño negatively impacts on the duration of rainy seasons with an average reduction of 62 days in Bondoukou, 25 days in Nassian, 20 days in Koun Fao,12 days in Bouna and 10 days in Tanda.

Table 4. Comparison of average duration of crops season in normal years El Niño

\begin{tabular}{llll}
\hline Stations & \multicolumn{3}{l}{ Averages length of cultural seasons (days) } \\
& Normal year & El Nino year & deviation \\
\hline Doropo & 146 & 148 & 2 \\
Bouna & 160 & 148 & -12 \\
Nassian & 86 & 61 & -25 \\
Koun Fao & 108 & 88 & -20 \\
Bondoukou & 123 & 62 & -62 \\
Tanda & 108 & 98 & -10 \\
Average & 121.8 & 100.8 & -21.2 \\
\hline
\end{tabular}




\subsubsection{Analysis of dry spells}

The calculation of probabilities for drought period more than 5, 7 and 10 days within 30 days from the date of beginning of the season for different measurements from stations helps us evaluate drought risks after the beginning of the crops season. The figures 5, 6 and 7 present the probabilities of comparing dry sequences for the different levels in normal years and in year El Niño.

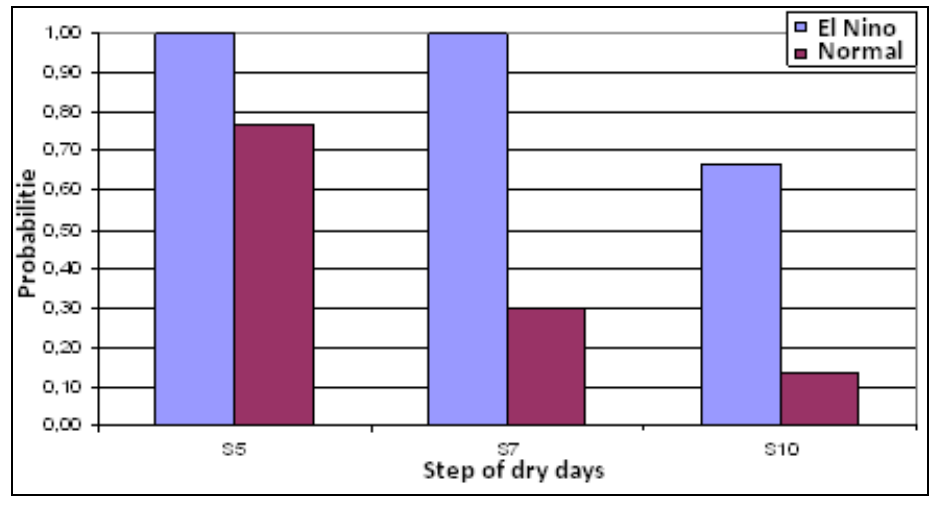

Figure 5. Probabilities of maximum dry periods beyond the levels of 5, 7 and 10 days for a period of 30 days after April 6, in Bondoukou.

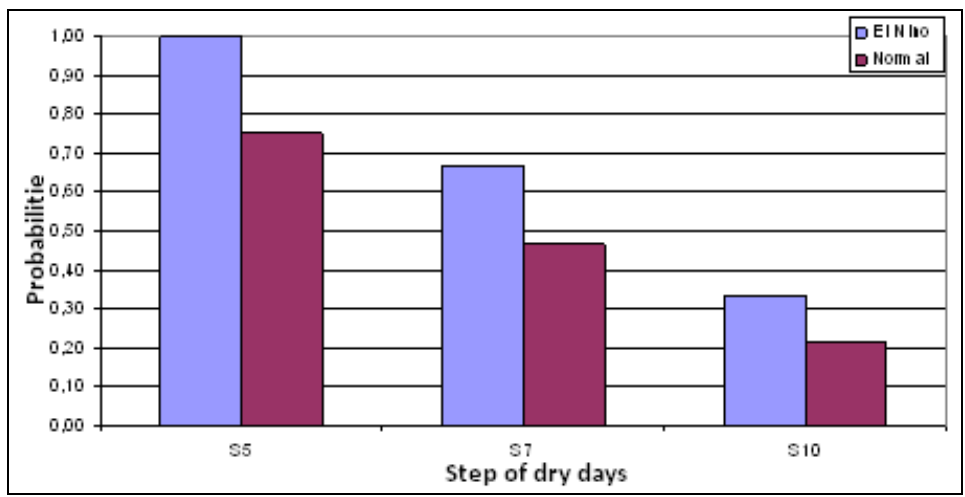

Figure 6. Probabilities of maximum dry periods beyond the threshold 5, 7 and 10 days for a period of 30 days after May 13, in Bouna.

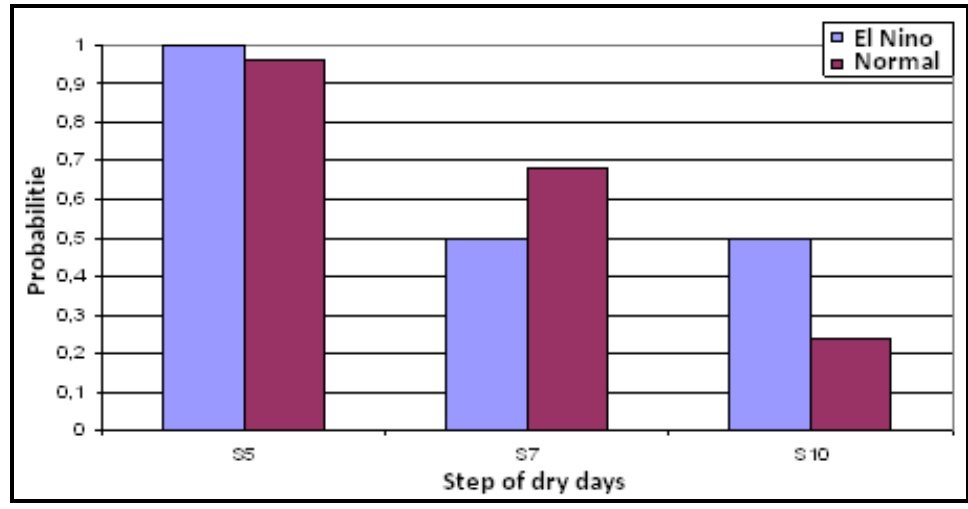

Figure 7. Probabilities of maximum dry periods beyond the threshold 5, 7 and 10 days for a period of 30 days after April 19, in Tanda

The probabilities for the maximum dry period over 10 days are:

- $67 \%$ in year El Niño for 13\% in normal year in Bondoukou. ; 
- $33 \%$ in year El Niño for $21 \%$ in normal year in Bouna ;

- $\quad 50 \%$ in year El Niño for $24 \%$ in normal year in Tanda.

The probabilities for maximum dry period to be over 5 and 7 days are in line with the same evolution period except the region of Tanda for the limitation of 7 days, the probability of being over it is more important in normal year than in the year El Niño.

\subsection{Discussion}

\subsubsection{Major rain irregularities caused by the phenomenon El Niño}

The issue of the phenomenon El Niño has caused a disturbance in rainfall noticeable with all the climatic measurement centers from the Zanzan region. This disturbance is mainly caused by a reduction in crops seasons, a modification in rainfall and drastic reduction in rain volume. In Bondoukou, rain gauge is defined as a packing down of the probability curve of rain in year El Niño, which confirms the delay in the advent of crops seasons. In year El Niño, the inter-season (small dry season) is so dry that it reduces the stock of groundwater. The new beginning of the second rainy season which does not last more than one (1) year does not make it possible the atmosphere system to keep enough dampness so that it can be an early dry season in the mid of October.

In Bouna, the phenomena El Niño make the peak of rain normally noticed in May and the rains are still insignificant till September where a short season of rains is noticed for about 1 month followed by a long dry season period. In Tanda, it is the second rainy season that disappears under the influence of the phenomena El Niño after a short rainy season ranging from May to June.

This study has highlighted that in the years El Niño, the rainy season is considerably modified in the Zanzan region. Those years are also characterized by significant deficits in rainfall on the season ranging from November to March marking the seriousness of the dry season. The juxtaposition of a long and severe dry season and stop duration of rain during the crop season is a handicap in the normal pursuit of agricultural activities and a variable permitting a hydrous pressure for crops.

The results indicating the significant impact of El Niño on agricultural activities are not documented enough by previous studies though the work of [18] did mention reduction in rainfall in the Zanzan region since the seventies. The results of this current study confirm those conducted by experts from [19] concluding that the phenomenon El Niño negatively impacts agriculture within all the African regions giving room to the continent for occurrence of drought causing a drop in crops production even on the local scale. These results take into account the study undertaken on climate in Africa as a whole by $[2 ; 23]$ " and in Cote d'Ivoire in particular by [24]. The El nino phenomenon is seen today as one of the tremendous changes in climate issues in Africa and in the study area.

\subsubsection{Agro-climatic damage in the Zanzan region}

Based upon the comparison of average duration of crop season in normal years and in years El Niño as indicated in table IV, it is clear that the duration of crop seasons in years El Niño is being reduced considerably. However, the reduction is changeable enough in space in the Zanzan region. The abovementioned episodes have caused a reduction in crop season in the Zanzan region for more than 40 days. The reduction in the duration of seasons has reached 86 days in Nassian in 1973, a reduction of $60 \%$ of the average duration of the season. In Bondoukou, the reduction in crop season was 70 days, a reduction of $5 \%$ during that year. For the period of 1983, the crop season underwent a reduction of 57 days in Koun Fao, 48 days in Bondoukou and 42 days in Bouna. For the episode of 1998, the reduction of rainy seasons was 24 days in Bouna, 38 days in Nassian and 63 days in Bondoukou. Those fluctuations in the duration of crop season caused a major prejudice to agricultural activities. From the agro-climatic characteristics of the Zanzan region, some cumulated hydrous deficits to some reductions in the duration of crop seasons undoubtedly brought about a depression of hydrous conditions. The northern region has a unique modal structure of its rainfall. When it is affected by heavy drought as indicated in the work of [19], the area is exposed to real risks, namely some bush fire destroying the flora and the fauna and sometimes some human settlements.

Those results are in line with a study conducted by [25] about the agro-climatic conditions in the eastern part of Côte d'Ivoire.

\section{Conclusion}


The climate in the Zanzan region is subject to noticeable variations with a disturbance on the levels of water's volume registered as well as in the classification of rain. These changes are aggravated with the occurrence of El Niño that negatively impacts the agricultural calendar. The years El Niño are the center for a delay in the advent of rain seasons, an extension of previous dry season and a reduction in the duration of the first season of rains. They are also marked by risks of drought more important after the beginning of rains.

In the framework of agricultural planning, many factors like the socio-economic situation of the peasant and variations in the type of soil are conditions for the efficiency of rains utilization for growth. However, the agro-climatic analysis that puts in relation the needs for water for crops and the provision for water by the rainfall limits the climatic risks for agricultural production as the needs for water for crop necessitates some minimum volume of rains to certain important stages. The point of this current study is the present capacity of climate science to foresee the phenomenon El Niño permitting to anticipate its impacts during agricultural activities.

\section{References}

1. GIEC, Résumé à l'intention des décideurs. In: Changements climatiques 2007 : Les éléments scientifiques. Contribution du Groupe de travail I au quatrième Rapport d'évaluation (AR4) du Groupe d'Experts Intergouvernemental sur l'Evolution du Climat. pp 2-22, 2007.

2. T. N. PALMER, Influence of the Atlantic, Pacific, and Indian oceans on Sahel rainfall. Nature, 322, pp. 251-253, 1986.

3. S. HASTEnRATH, L.C. DE CASTRO, P. ACEITUNO, The Southern Oscillation in the Tropical Atlantic sector. Beitr. Phys. Atmosph., 60, 447-463. 1987.

4. K. WOLTER, Modes of tropical circulation, Southern Oscillation, and Sahel rainfall anomalies. J. Climate, vol. 2, pp. 149-172, 1989.

5. M. N. WARD, Provisionnaly corrected surface wind data, worldwide ocean-atmosphere surface fields, and Sahelian rainfall variability. J. of Climate, 5, 454-475. 1992.

6. T. N. PALMER, C. BRAKOVIC, P. VITERBO, M. J. MILLER, Modeling interannual variations of summer monsoons. J. Climate, vol. 5, pp. 399-417, 1992.

7. TRZASKA, S., V. MORON, B. FONTAINE, Global atmospheric response to specific linear combinations of the main SST modes. Part I: numerical experiments and preliminary results. Ann. Geophys., vol. 14, pp. 1066-1077, 1996.

8. B. FONTAINE, S. TRZASKA, S. JANICOT, Evolution of the relationship between near global and Atlantic SST modes and the rainy season in West Africa: statistical analyses and sensitivity experiments. Climate Dyn., vol. 14, pp.353-368, 1998.

9. S. JANICOT, J. POLCHER, S. TRZASKA, I. POCCARD, Decadal scale variability of summer Sahel-ENSO teleconnection. Soumis a Climate Dyn, 1999.

10. O. HOFFMANN, Recherche sur les transformations du milieu végétal dans le nord-est ivoirien: les pâturages en pays Lobi. Paris : ORSTOM, Th. 3e Cycle : Géographie. Tropicale: Bordeaux 3. $299+81$ pIRI, 2006. ENSO Bulletin. International research Institute for Climate and Society, 1983.

11. Ministère de l'Agriculture et des Ressources Animales (MINAGRA), Direction des Statistiques, de la Documentation et de l'Informatique (DSDI), 2001- Recensement National de l'Agriculture. Abidjan, Côte d'Ivoire, $57 \mathrm{p}$.

12. Y. T. BROU, Analyse et dynamique de la pluviométrie en milieu forestier ivoirien : recherche de corrélations entre les variables climatiques et les variables liées aux activités anthropiques. Thèse de Doctorat 3ème cycle, Abidjan, 210 p, 1997.

13. NOAA, NOAA/ National Weather Service NOAA Center for Weather and Climate Prediction. Climate Prediction Center 5830 University Research Court College Park, Maryland 20740, 2014.

14. STERN, Instat+ Climatic guide. Statistical Services Center, University of Reading, Reading, U.K, 2002.

15. M. V. K. SIVAKUMAR, Predicting rainy season potential from the onset of rains in Southern Sahelian and Sudanian climatic zones of West Africa. Agricultural and Forest Meteorology vol. 42, pp. 295-305, 1988. 
16. B.T.A.Goula, B. SROHOUROU, A. B. BRIDA., K. A. N'ZuÉ, G .GOROZA, Determination and variability of growing seasons in Côte d'Ivoire. International Journal of Engineering Science and Technology, Vol. 2(11), pp. 5993-6003, 2010

17. R. D. STERN, J. KNOCK, H. HACK, Instat Climatic Guide. Statistical Services Center, University of Reading, Reading, U.K. 156p, 1989.

18. NOUFE, Changements hydroclimatiques et transformations de l'agriculture : l'exemple des paysanneries de l'Est de la Côte d'Ivoire. Thèse de doctorat, spécialité géographie. Université Paris 1 Panthéon-Sorbonne U.F.R. de géographie UMR 8586 PRODIG, pp. 177-206, 2011.

19. D. NOUfE, B. LIDON, G. MAHE, E. SERVAT, J. L.CHALEARD, Impact de l'évolution des conditions agroclimatologiques sur les systèmes de culture à base de banane plantain : le cas de l'Est ivoirien. VertigO - la revue électronique en sciences de l'environnement, Vol. 15 n0 1, 2015.

20. Servat E., Paturel J. E., Kouamé B., Travaglio M., Ouedraogo M., Boyer J. F., Lubes-Niel H., Fritsch J. M., Masson J. M. et Marieu B., 1998, Identification, caractérisation et conséquences d"une variabilité hydrologique en Afrique de l'Ouest et Centrale. IAHS Publication, n²52, pp. 323-337.

21. Lubès-Niel H., Masson J. M., Paturel J. E. et Servat E., Variabilité climatique et statistique. Etude par simulation de la puissance et de la robustesse de quelques tests utilisés pour vérifier l'homogénéité de chroniques. Rev. Sci. Eau, 11(3), pp. 383-408, 1998.

22. Hulme1 M., Doherty R., Ngara T., New M., Lister D., African climate change: 1900-2100. CLIMATE RESEARCH, Vol. 17: 145-168, 2001.

23. Kouakou K. E., Kouassi A. M., Kouadio Z. A., Goula B. T. A., and Savane I., Modélisation hydrologique du bassin versant de la Comoé dans un contexte de changement climatique. International Journal of Innovation and Applied Studies Vol. 15 No. 4, pp. 799-811, 2016.

24. Brou T. Y., Servat E. et Paturel J. E., Contribution à l'analyse des interrelations entre activités humaines et variabilité climatique : cas du sud forestier ivoirien. Académie des sciences/Elsevier, Paris, t.327, série II a, pp.833-838. 1998.

25. R. Y. N'GUETTIA, S. O. DOFiSSI, B. KOFFI and L. FONDIO, Déclin de la pluviosité en Côte d'Ivoire : impact éventuel sur la production du palmier à huile, Sécheresse, vol. 6, pp. 265-271, 1995. 